\title{
Beyond the Species Barrier: the Health Council of the Netherlands, legitimacy and the making of objectivity
}

Citation for published version (APA):

Hendriks, R. P. J., Bal, R. A., \& Bijker, W. E. (2004). Beyond the Species Barrier: the Health Council of the Netherlands, legitimacy and the making of objectivity. Social epistemology, 18, 267-295.

https://doi.org/10.1080/0269172042000249000

Document status and date:

Published: 01/01/2004

DOI:

10.1080/0269172042000249000

Document Version:

Publisher's PDF, also known as Version of record

\section{Please check the document version of this publication:}

- A submitted manuscript is the version of the article upon submission and before peer-review. There can be important differences between the submitted version and the official published version of record.

People interested in the research are advised to contact the author for the final version of the publication, or visit the DOI to the publisher's website.

- The final author version and the galley proof are versions of the publication after peer review.

- The final published version features the final layout of the paper including the volume, issue and page numbers.

Link to publication

\footnotetext{
General rights rights.

- You may freely distribute the URL identifying the publication in the public portal. please follow below link for the End User Agreement:

www.umlib.nl/taverne-license

Take down policy

If you believe that this document breaches copyright please contact us at:

repository@maastrichtuniversity.nl

providing details and we will investigate your claim.
}

Copyright and moral rights for the publications made accessible in the public portal are retained by the authors and/or other copyright owners and it is a condition of accessing publications that users recognise and abide by the legal requirements associated with these

- Users may download and print one copy of any publication from the public portal for the purpose of private study or research.

- You may not further distribute the material or use it for any profit-making activity or commercial gain

If the publication is distributed under the terms of Article $25 \mathrm{fa}$ of the Dutch Copyright Act, indicated by the "Taverne" license above, 


\title{
Beyond the Species Barrier: The Health Council of The Netherlands, Legitimacy, and the Making of Objectivity
}

\author{
Ruud Hendriks, Roland Bal \& Wiebe E. Bijker
}

The Health Council of the Netherlands is an independent scientific advisory board to the Dutch government in matters of public health. In this article we argue that even for an independent body such as the Health Council there seems to be no escape from the increasing intertwinement of scientific and societal processes. In order to produce a serviceable truth for policymaking, the council needs to reflect on what goes on in its socio-political surroundings. On the other hand, how could we ever come to understand the legitimacy of the council when notions of scientific objectivity dissolve in such a reflexive, inherently political stance? In a situation where science and society are thoroughly interrelated, the Health Council somehow succeeds in bringing about or re-claiming some sense of objectivity. Our central question will be how to conceptualise this notion of 'objectivity' without having to rely on idealized notions of objectivity that are criticized in philosophical, sociological and historical studies of science and society. In order to do so, we will regard the objectivity of advisory reports of the Health Council as being constructed out of heterogeneous elements and under complex circumstances. The theoretical point will be empirically underpinned with case material drawn from activities of the Health Council in the period 1985-2002 in predominantly the subject areas healthcare and medical technology.

Keywords: Objectivity; Expertise; Construction; Hybrid; Health Council of the Netherlands; Scientific policy advise

\footnotetext{
Ruud Hendriks is a lecturer in the Department of Philosophy of the Faculty of Arts and Culture at the Universiteit Maastricht. Roland Bal works at the Department of Health Policy and Management of the Erasmus University Medical Centre in Rotterdam. Wiebe Bijker is professor of technology and sociology in the Faculty of Arts and Culture at the Universiteit Maastricht. Correspondence to: Dr Ruud Hendriks, Faculty of Arts and Culture, Universiteit Maastricht, P.O. Box 616, 6200 MD Maastricht, The Netherlands. Email: Hendriks@philosophy.unimaas.nl
} 


\section{Introduction}

Which subject did the Health Council of The Netherlands-scientific advisory board of the Dutch government and parliament regarding issues of public health-not address in its advisory reports?

Arsenic in wallpaper (in 1908)

Benefit of population screening for breast cancer with mammography (2001)

Consequences land reclamation Zuiderzee for spreading of malaria (1928)

Dementia (2002)

Ethics of genetic counseling (1980)

Facilities and costs kidney transplantations (1977)

GSM-base stations (2000)

Hygiene of water, soil and air as regards the peaceful application of nuclear energy (1958)

Impact of the current circumstances on mental health of youngsters (1940)

Judicial status import-ban on parrots (1938)

Kidney transplantation and haemodialysis (1968)

Lead in tap water (1912)

Medical objections against indirect enforcement of smallpox vaccination (1910)

Nuisance by dust caused by car traffic (1908)

Ozone (1988)

Psychedelic sound in beat music (1967)

Quarantine station at Kamaran (1925)

Reconsidering the policy on HIV testing (1999)

Smoking and lung cancer (1956)

Training and exam district nursing (1933)

Ultrasound in physiotherapy (1985)

Vitamin content of rose hips (1941)

Wood dust; evaluation of the carcinogenicity and genotoxicity (1998)

Xenotransplantation (1998)

Yttrium and yttrium compounds (2000)

Zinc (1997)

This tiny $\mathrm{ABC}$ of Health Council's advice through the years-although only a fraction of the more than 2000 advisory reports the council has published during its 100 years of existence-not only operates as a simple time-traveling machine. ${ }^{1}$ These examples also testify to the complexity of problems in the area of public health. Glancing over the range of subjects the Health Council has been advising on-a wide and varied domain covering contagious diseases, medical technology, food safety, occupational health hazards, etcetera-one feels a witness to what Bruno Latour (1993) has called the proliferation of hybrids. Chemical substances enter the human body by means of food and the water supply, war and the threat of war force themselves on the public's mental and physical health, a socially acceptable appliance of medical-technological innovations requires a neat balance between governmental power and individual freedom. In sum: the kind of problems the Health Council faces are in many respects of a cross-border nature.

The topic-list above is no less indicative of the trust invested in science to help to solve such problems, and thus to contribute to the progress of society. At the beginning of the twentieth century this growing belief marked the end of a period of 
governmental noninterference regarding issues of public health and resulted in the establishment of the Central Health Council (in 1902), predecessor of the present Health Council that was installed in $1920 .^{2}$ Nowadays, the Health Council is an independent advisory board with the statutory task to advise the Dutch government and parliament on the current level of knowledge with respect to public health issues. $^{3}$ It has developed into an organization of more than 200 members: leading experts in their discipline who work at universities and/or are active in relevant societal sectors (e.g., clinical settings, governmental research institutes). Advisory reports are prepared in independent, multi-disciplinary, ad hoc committees composed of members and non-member experts. Their work is supported by the secretarial office of the Health Council in The Hague-an organization with a staff of 60, about 30 of whom serve as scientific secretaries to the committees.

Along with the complexity of the problems of our time, confidence in scientific advice seems only to have increased: there is a growing reliance on experts when it comes to coping with social (policy) problems. Although the tendency has been criticized in terms of its democratic deficit, policy-making at the beginning of the twentyfirst century seems no longer conceivable without scientific input. On the other hand, the independent status of science itself seems to be under growing pressure too. It may no longer be exceptional for a scientist to know his or her way around in The Hague or Brussels, society has found its way to the laboratory as well. In that sense, science has become increasingly politicized. Constructivist studies of science even suggest that scientific appeals to objective truths play an ideological part. But we need not embrace such a radical claim in order to see that the cultural authority of science shows signs of wear and tear, and agree with Dick Pels $(2001,6)$ that ' $[t]$ he dropping of classical dichotomies between truth and interest, rationality and politics, or facts and values meant ... that at least they were no longer considered capable of effectively patrolling along the Great Wall between science and society-which therefore began to founder and collapse more and more'. ${ }^{4}$

The idea that science is confined to the laboratory whereas politics is to be found in The Hague and Brussels, thus seems to require qualification. ${ }^{5}$ Even for an independent body such as the Health Council, we will argue, there seems to be no escape from increasing intertwinement of scientific and societal processes. As an advisory board the Health Council has to translate scientific knowledge into a serviceable truth for policy and society. ${ }^{6}$ In order to do so successfully, the council needs to reflect on what goes on in its socio-political surroundings. Although formally a purely scientific advisory board, in practice the council therefore turns out to include all kinds of non-scientific elements in its advisory work. ${ }^{7}$

On the other hand, how could we ever come to understand the legitimacy of the council when notions of scientific objectivity dissolve in such a reflexive, inherently political stance? We can hardly imagine the work of the Health Council without an idea of objectivity, and of 'experts who put their knowledge at society's disposal in a disinterested way' (Gezondheidsraad 2000, i). The council's autonomy is of crucial importance for safeguarding its scientific authority, something that cannot be overruled by the need to anticipate on policy and society. A balanced analysis of the council's work 
and a better understanding of the societal respect for and impact of its advisory reports (which both are beyond doubt) thus compel us to take serious the constitutive character of the notion of objectivity.

Our analysis seeks to contribute to a better understanding of the role of objectivity in legitimizing scientific advise for public policy-making. The central question will be how to conceptualize 'objectivity' without having to rely on idealized notions of objectivity that are criticized in philosophical, sociological and historical studies of science and society, that is: without doing away with the insight that objectivity needs to be reclaimed or brought about in a situation where science and society are thoroughly interrelated, and the cultural authority of science is no longer self-evident. In order to do so, we will regard the objectivity of advisory reports of the Health Council as being constructed out of heterogeneous elements and under complex circumstances. The theoretical point will be empirically underpinned with case material drawn from activities of the Health Council in the period 1985-2002 in predominantly the subject areas healthcare and medical technology. ${ }^{8}$

\section{Framing the Problem}

In its Annual advice Healthcare 1994-1995 the Health Council signals renewed scientific and social interest for xenotransplantation - the transplantation of an animal organ to a human being. ${ }^{9}$ In doing so, the council calls attention to a type of problem our technological culture seems to collect by the dozen: problems that can no longer be known or solved in purely political or exclusively scientific terms. In this case we are not only dealing with an object that 'has in fact already transgressed the species-barrier [between pig and primate]', ${ }^{10}$ as it was put by the committee that would be installed in due course by the Health Council to answer a ministerial query about this subject. Also the opportunities and problems-such as severe safety hazards and ethical and social issues - that are imminent to the as yet hypothetical use of (transgenic) animals for transplantation goals, in various ways transgress species-barriers. In Nik Brown's (1999) words: 'Xenotransplantation hybrids are complex contradictory productions which vividly trouble the boundaries between humans and animals, science and culture, emotion and rationality, expert and lay identity' (328).

Apart from suggesting a possible subject for advice, the Health Council presents itself as an advisory body claiming ownership (cf. Gusfield 1981) for this kind of complex problems, if only for the duration of the advisory process. The council's claim on having a say in these matters was acknowledged in December 1996, with a request for advice from the Minister of Health about the current level of knowledge concerning xenotransplantation. Questions that would inform the deliberations in the Xenotransplantation Committee were formulated-as is customary-after close contact between representatives of the council and the ministry. ${ }^{11}$ These questions concerned: the scientific developments to be expected in this domain, with special attention for possibilities and objections regarding rejection, physiological function, and the risk of infection with pathogens hosted by animals (1); the ethical acceptability of breeding genetically 
modified animals for this goal (2); the form of ethical judgment prior to any future clinical research with people (3); and the adequacy and appropriateness of existing and forthcoming legislation for covering further development and use of xenotransplantion (4).

Notice that the problem as it is framed in the query for advice thus plays a crucial part in acknowledging the hybrid character of problems of our time, as well as it pays testimony to the Health Council's ambition to cope with this complexity in its advisory reports. Thanks to the specific expertise at hand, the Health Council according to its own account is well equipped to prepare advisory reports in which the state of science, ethical, legal and social issues are addressed in an integrated way. The scientific secretary of the council's Standing Committee on Medical Ethics and Health Law describes this ambition as follows:

It's not only to sum up the current level of knowledge-conceived as an amount of research outcomes on a certain topic — in a cut and dried way. For us it's much more. For us there's also a kind of weighing and interpretation implied, and to follow the line to what something could imply for policymaking, to what it means with regard to value-laden discussions in society. ${ }^{12}$

This aim, however, does not mean that the council throws the door wide open to the outside world; delineation of the problem to feasible proportions is most urgent. Restriction serves several purposes, the most interesting one for us is the following: from the outset the council is not only supposed to chart various aspects of the hybrids that seem to be here to stay, but also to explore possibilities of control over the obscure and partly illegitimate liaisons that science, technology and human values have begun to entertain. Outside the scope of national law, careful news coverage and realistic expectations, scientific progress in the case of xenotransplantation research, for instance, turns out to have engaged in monstrous alliance with international commerce, the media circus, and irrational hope in the general public.

Genetically modified, transgenic animals are bred in only some places in the world, most often with commercial objectives. With these animals or their organs as commodity international business traffic will arise. National legislation will not be sufficient to regulate these transactions. Partly thanks to the indicated involvement of trade and industry, important scientific progress has been made over the past few years to reduce the immune response that occurs immediately after a xenotransplantation. Publicity around these positive results has stirred social interest in xenotransplantation. ...Patients expect xenotransplantation to provide a solution for their health problems and exert pressure to speed up the developments. ...At the same time, involvement of the industry entails the risk that because of business-policy reasons scientific information is not always made public. This hampers an adequate and up to date overview of the level of scientific knowledge. (Gezondheidsraad 1998a, 20)

Such long-distance relationships, the Health Council knew, would not much care about political or geographical boundaries. The hype that had rolled over Britain could easily jump over to The Netherlands. ${ }^{13}$ The minister had been confronted with questions in parliament (Tweede Kamer 1996a). Clinical experiments in humans did not seem far away at that time; the biomedical industry had already contacted the Ministry 
of Health, Welfare and Sports about legal possibilities for xenotransplantation research in The Netherlands. ${ }^{14}$ Emeritus professor of cardiology, Dunning, who was found willing to chair the Xenotransplantation Committee speaks of a 'sense of urgency': ${ }^{15}$ advice from the Health Council should help to prevent that the government would be confronted with a fait accompli. That is why the council was asked to see into the future-formally to advice about the current level of scientific knowledge, but as we like to stress here also in order to bring these hardly known entities under official rule.

As we will argue below, it is precisely in the light of this quest for control (and limits to that endeavor) that it makes sense to think of the Health Council's societal authority in terms of 'objectivity'. Notice that in order get to know the hybrid monsters that are conducted in the advisory process in a way that opens possibilities for their domestication, they are caught in a style of questioning that suggests the answers to come from tested procedures, bureaucratic forms, and certified styles of reasoning. A clear example is question (4) about the adequacy and appropriateness of existing and forthcoming legislation for covering a new phenomenon such as xenotransplantation. In line with this question, the committee would for instance address the problematic status of human recipients of a genetically modified animal organ, if this were to become a reality. Under the current law these organs fall under the legislation on genetically modified organisms (GMOs).

As such, the recipient would come within the scope of the Environmental Hazardous Substances Act and the associated regulations. The committee considers this undesirable, as this body of law was not formulated with medical applications in mind; it intended to protect the population at large, rather than the health of individual patients. The committee would therefore like to see the recipients of genetically modified animal organs explicitly excluded from the scope of the Act. ${ }^{16}$

Human carriers of GMOs are the proverbial hybrid; they do not fit legislative categories coined in times of more clear-cut distinctions between humans, animals and machines. ${ }^{17}$ In order to save these patients from an improper, quasi-official existence-as environmental hazardous human substance-legislation that is geared to their hybrid constitution must be developed, the council says. Thus, the council seeks to meet its task to not only represent the strange new entities that come to populate our world, but also to further extend possibilities of (legal) command.

Still, there are limits to the degree of complexity that can be accommodated; this type of questioning also implies a filter on what is allowed in the advisory process. ${ }^{18}$ Even in cases that demand ethical reflection, the idea of social management that mostly motivates a query for advice necessarily sets limits to what can and cannot be taken into account. The statutory task of the Health Council implies that the council should restrict itself to a scientifically sound ethics that yields relevant insights for, and is serviceable to policy-making. As the Minister of Health has said in response to questions in Parliament about the Health Council's task: '[Where relevant] insight in the level of knowledge ... that has been formulated as objective as possible, is complemented with a scientifically sound, ethical and legal consideration' (Tweede Kamer 1996b, 5). A debate in the council's Standing Committee on Medical Ethics and Health Law makes clear that these requirements are usually understood to imply that the 
council must base its analyses solely on argumentations that are independent of specific conceptions of the good life and thus can in principle be shared by all citizens. Usually, it is also in this respect that a notion of objectivity is claimed:

A scientifically sound ethics is considered to be an ethics of which the analyses and argumentations are [entitled to be labeled] objective insofar they are not phrased in terms of a particular (e.g., the christian, the islamic, the humanistic) view on what is good for people. ${ }^{19}$

Questions that are usually considered appropriate in such 'as objective as possible, scientifically sound ethics' concern potential health gains and risks, implications for individual freedom, and privacy protection. Normally excluded, because rooted in religious convictions or political ideologies, are questions regarding the 'intrinsic value' of human life, embryo's or animals. ${ }^{20}$

Indeed, such a partition also seems to be effectuated in the case of xenotransplantation, where animal integrity was on the agenda, but the room for discussing the matter seems to have been kept rather small (which was in fact criticized by some of the committee members as well as in the Standing Committee on Medical Ethics and Health Law). ${ }^{21}$ If the problem was not yet clearly delineated in the minister's query, ${ }^{22}$ the committee's chair can be praised (or criticized) as the secretary points out:

These [issues such as animal integrity] may also be topics that can be extensively discussed since everybody (and thus nobody) is an expert in these matters. In the end consensus was reached, not in the least because the chair was determined to not let discussions get out of hand and managed to steer the process in the right direction. ${ }^{23}$

One type of question that is definitely denied access has to do with 'so-called "rest" problems, vague feelings and moral intuitions' as they are referred to in public discourse on xenografting studied by Medard Hilhorst $(1998,194)$. Contrary to the consensusoriented conceptual, analytical and rational ways of arguing usually seen in social ethics (and one might add: in the Health Council's objectified notion of ethics), such personal feelings and emotions-Are all organs just organs? What is our human destiny? How does it feel to have an organ from an animal?-tend to polarize and precisely to lead away from consensus. ${ }^{24}$ This does not sit well with a political sense of urgency. Hilhorst: "The idea of the "social management" of modern biotechnology seems to point rather in the opposite direction, namely to reduce as much as possible the differences of opinion within society'. ${ }^{25}$ This would explain why such issues are usually discredited as 'irrational and fleeting' (Brown 1999, 352). Being denied an official public existence they keep popping up in the newspaper headlines studied by Brown, where ' $\mathrm{t}$ ] he frequent use of "yuck" represents a recourse to a repertoire of nascent, embodied, intuitive feelings' (p. 336), that dismisses the real sensitivities behind.

To expect the Health Council to include such unarticulated, personal, intuitive, embodied feelings as part of the problem would certainly provide a challenge for the way it has taken up its ambition to deal with the hybrid problems of our time. In fact, the discussants in the Standing Committee on Medical Ethics and Health Law quoted already defend a broadening of the scope of a scientifically sound ethics and of the notion of objectivity. They question the assumption that ethical objectiv- 
ity can be found by choosing basic principles that are neutral vis-à-vis particular conceptions of the good life. The reduction of 'objective' ethical discourse to considerations of autonomy and the like are as indebted to a particular (i.e., liberal) worldview as any. They conclude:

The requisite of a 'scientifically sound ethics' cannot be used in advance to exclude from the discussion certain moral considerations (the ones which are indebted to religious or philosophically determined principles) as being 'less objective'. Yet, the Health Council in its ethical advice should still appeal to arguments that can count on the broadest possible public support. Where such consensus lacks, the Council must exercise restraint. $^{26}$

In cases where there is less political urgency, inclusion of more fundamental questions might be possible and desirable, the discussants hold. The advice on xenotransplantation may have been one of these occasions. ${ }^{27}$ On the other hand, it seems likely that inclusion of what is now often delegated to the private sphere-'taking up the position ... that everybody should know and decide for himself' (Hilhorst 1998, 195) _ would have put the council's established (certified, rational, bureaucratic) frames of reference under tremendous pressure. Indeed, it was presented as a matter of opinion'We say: it's an opinion, an opinion of this committee, of people who came to the conclusion on personal grounds that there are no objections in principle ${ }^{28}$ - that xenotransplantation, were it to become a reality, in principle would not affect human dignity, while acknowledging that 'others for instance on religious or cultural grounds could come to an opposite opinion on this' (Gezondheidsraad 1998a, 35).

'Objectivity' in a context of hybrid liaisons and fuzzy boundaries asking for rapid political action, should be conceived not as a noun but as a verb, 'objectifying'. Objectifying in this stage of the advisory process takes the form of imposing filters (by formulating precise questions) in order to sort things out: hybrid constellations that are likely to fit the council's established ways of coping (reasoning, analyzing) are allowed in to see whether they can be brought under official rule; those complexities that risk to escape the Health Council's trusted upon procedures and threaten to foster endless debate cannot pass and become what we could call 'subjectivity in the wild'.

\section{Reconfiguring the Expert}

Not only the subject of advice is in need of further delineation, also the social surroundings in which the problem is to be discussed needs to be prepared. For composing a committee the council can rely upon an extended network of experts in- and outside of its own circle of members. The experts that make up the network can be considered the gold of the Health Council. The composition of committees is a means for the council to position itself vis-à-vis its surroundings. The authority of individual members and the council at large are communicating vessels. In controversial situations it is crucial to select experts who are not in the least connected to the social context at stake. By taking an academic detour and sometimes even turning abroad in order to find experts who will be regarded as impartial by the field, the council can try to take the political sting out of the deliberations. ${ }^{29}$ This, on the other hand, does not 
mean that committee members should be disengaged figures. Neutrality of the council is not offered on the altar of absolute detachment.

Whereas it is the council's aim to follow the line from facts to what they mean with regard to value-laden discussions in society (cf. the previous section), putting together a committee demands a selection of experts who are reputed not only for their knowledge, but also for their engagement with certain sectors, acknowledged as authorities within their discipline, etcetera. Such engagement should not be confused with defending a political preference or a particular interest, which is a pitfall the council will avoid at all costs. What, however, the council will never avoid is scientific dispute. Former president of the Health Council, Ginjaar: 'I tried to have people in committees from different disciplines and within these disciplines of course also with different views; in the scientific domain that's just fine'. ${ }^{30}$ Vice-president at the time of research, now president of the Health Council Knottnerus confirms: for a qualitatively sound advice a 'good debate on the analysis and recommendations' is needed. When forming a committee one 'must not only take expertise into account, but also ask: where's the scientific debate?' Finally, one needs to make sure that the experts engaged in such a debate 'can also be admitted in a committee collectively'. ${ }^{31}$ Instead of people who may oppose one another like fighting cocks, it is crucial to find experts for whom scientific dispute is a form of collaboration.

Members of Health Council committees are recruited as bearers of knowledge, insight, and problem solving abilities, but they also bring along risks for the institute at large. As raw human material they are extracted from the outside world, but in order to make a committee run as a smooth advisory device, their actions must also be controlled. Let us focus on some rules of the house that the Health Council developed in order to make the-by definition unpredictable-human factor as productive as possible. These rules may be understood as conditions to promote the objectivity of the committee process.

In the first place, members of the committees are not allowed to have themselves replaced by someone else: 'The members take their seat in committees exclusively in their personal capacity and cannot send a stand-in in case of absence' (Gezondheidsraad $2002,8)$ as it is phrased in the 'blue brochure' that instructs new committee members. The reason for this rule is that members are not supposed to represent interests or other authorities and to speak exclusively on their own account-'unburdened and without consultation'. Secondly, committee members do their advisory work gratis. In that sense too, the council depends on experts 'who put their knowledge at society's disposal in a disinterested way' (Gezondheidsraad 2000, i). To put emphasis on committee members doing their work unsalaried is more than a compliment at the members' addresses. It is part and parcel of the fine-tuning of the committee member's attitude to not distract them from considering their membership as an honorary post. 'At the moment that you have financial interests to enter a committee, false motives may start to play a role too'. ${ }^{32}$

In both senses of the term, 'disinterested contributions' seems to refer to a somewhat anachronistic kind of expert, reminding us of Mertonian norms of science. Disinterestedness, however, has overtime become an ever more complex matter. Even for an 
independent board such as the Health Council there is no escape from the increasing intertwinement of scientific and social processes. This definitely applies to the council's doings with potential committee members, since professional activities of these have become more and more embedded in knowledge institutes with links to trade and industry, governmental or other producers and consumers of knowledge (cf. de Wilde 2001). Rather than a ghost from the past, the emphasis on disinterestedness is a way to cope with experts who themselves became hybrids.

The case of xenotransplantation is no exception to this rule: highly regarded experts in this field seem to exemplify the increased interrelatedness of science, industry, national and international health policy. ${ }^{33}$ Also on this level species-barriers evaporated. However, the fact that the virologist Osterhaus and his collegue Grosveld, a molecular biologist, were member respectively of the Safety- and Scientific Advisory Board of Imutran-the biotech company that pioneered in experiments with transgenic pig hearts-does not mean that the Health Council was able or willing to pass them by when it came to putting together a committee. Just like the council has found ways to deal with hybrid problems, it has apparently also learnt to live with the fact that the expert working in splendid isolation belongs to the past.

How does the council-because of its constituent parts, an institute beyond the species-barrier itself!- - keep up its legitimizing standards of objectivity (i.e., disinterestedness)? A procedure that was recently formalized by the Health Council provides an answer. It concerns the disclosure procedure that is meant to provide insight in any possible conflicts of interest committee members might have. This procedure was already good practice at the time of the installation of the Xenotransplantation Committee. It is also the latest weapon in a battle already described by the former executive director of the council, Rigter, 15 years ago. Rigter (1987) points out that the pursuit of what he calls 'private interests' ( $p$. 143) by committee members is always a possibility and thus should be fought. The Health Council has combated such selfinterest by compensating any bias on a committee and organizational level, for instance by means of a balanced composition of the committee, organizing hearings, sound literature dossiers, and a peer review system.

Nowadays, the combat is no longer against what used to be a 'pursuit of self-interest' but against what has become a 'possible conflict of interests' that is considered to be immanent to the expert's role in knowledge society (cf. the explanation below). Whereas the focus in terms of the threat has shifted from individual weakness to the hybrid qualities of the collective, the focus in terms of a remedy, however, has moved in the opposite direction. Whereas it used to be the system that needed to compensate for individual flaws, it has now become the individual who is mobilized to save the ideal of objectivity: your open-minded judgment-'uw onbevangen oordeel'-benefits from your sincerity-'openheid'-regarding any interests you may have, is the message to new committee members. But although the rhetoric is one of spontaneous personal virtues to be appealed upon, it is important to keep in mind that we witness the coming into being of a new entity: a carefully crafted, sincere, open-minded, engaged but unprejudiced member of a life-form called the Health Council. 
This transformation of the 'ordinary' expert into a committee member is realized by a combined set of literary and social technologies. A recent draft of the Manual for secretaries includes the issue 'Conflict of interests' for the first time. The description reads as follows:

Committee members may have interests that could interfere with an open-minded judgement on the subject of the advice to be formulated. For that purpose they are asked to provide openness regarding these interests vis-à-vis the president of the Health Council and their fellow committee members. When the committee meets for its installation the subject will be addressed by the committee's chair. (Gezondheidsraad 2001, 29)

Committee members sign a statement in advance and the president of the council addresses the issue during the installation. The explanation runs:

Committees of the Health Council are supposed to publish an advice that is based on an unprejudiced weighing of scientific data, facts, circumstances and views. Committee members are appointed in that capacity personally, because of their special expertise regarding the query for advice to be dealt with.

It is acknowledged that committee members may have or represent interests precisely because of this expertise. As such this need not present an obstacle for membership of a Health Council committee. Transparency in any possible conflict of interest however is important, vis-à-vis the chair and other members of the committee, as much as to the president of the Health Council. In the introductory round during the installation meeting members are asked briefly to give insight in the functions they hold and any possible other interests that could be of relevance for the work of the committee. By means of a form committee members have declared to be willing to provide that openness.

Occasionally it may be better if one is not appointed as committee member or that one withdraws as a member during the advice trajectory. Membership can alternatively be changed into a consultant position, in order to preserve important expertise for the committee. Unlike a member, a consultant does not carry responsibility for the advice to be published. (p. 29-30) 34 $^{3}$

Experts are asked for a committee primarily because they are expected to provide high quality substantive contributions. However, the best expert not necessarily equals a good committee member. Nor does it suffice to have a bunch of experts meet. What is needed to enhance deliberations among committee members and to turn substantive contributions into a sound advice is the stage setting of the committee process. ${ }^{35}$ On the one hand, staging is directed towards the organization of a discussion between members. On the other hand, dispute among experts as such is not valued here as it is in academic settings. Although a useful tool for mobilizing expertise, deliberations finally have to be directed towards a-preferably unanimous-answer to policy questions. Consultation between the secretary and the chair of the committee is crucial in this respect. By inviting committee members to produce oral or written contributions or by formulating specific questions in draft reports, secretary and chair try to stimulate an exchange of views. By shortcutting discussions or repairing contributions that are considered too far off track, deliberations are managed to stay within certain limits. ${ }^{36}$ 
An important quality of committee deliberations the council aims at is the 'onbevangenheid' of the contributions-this time not so much in the sense of an unprejudiced appraisal mentioned before ('onbevooroordeeld'), but rather in the second sense of the frankness ('onbeschroomdheid') of contributions. Opening the floor for discussion this time is therefore a matter of opening mouths rather than opening minds. To enable the committee members to come out into the open, the proverbial 'confidentiality of the committee process' functions as what we would like to call a technology of speech: 'It makes that you're slightly more free in your movements, and that people are more prepared to speak their minds, and that's what you want', Knottnerus explains. ${ }^{37}$ The confidentiality depends on material, discursive and legislative measures, such as new members being instructed to 'respect the confidentiality of the committee process and to not discuss that process with third parties' (Gezondheidsraad 2002, 13), while not complying to this norm may imply formal sanctions. ${ }^{38}$ Since 1997, the council has come under the regime of the Public Disclosure of Government Information Act which implies that the council can be asked to disclose information on the committee process - a threat to its confidentiality the council tries to counter by reserving the right to exclude documents that are still 'in preparation' or that concern 'personal policy-opinions' 39

'Objectivity' in a context of hybrid liaisons and fuzzy boundaries - this time not on the substantive but on a procedural level-again takes the form of controlled entrance. Objectifying mechanisms such as the disclosure-procedure play on the individual expert: a hybrid personality who is immanently connected to a variety of social worlds, and thus must be carefully prepared and molded to fit the form of life of the scientific advisory board. But control over the obscure and partly illegitimate liaisons that science, commerce and the state have begun to entertain, also extends to the experts once they are allowed in. Technologies of speech open the floor for an exchange of views between experts who are encouraged to come into the open. Thus, conditions to further the objectivity of the committee process combine internal transparency (in order to open minds) with external confidentiality (in order to open mouths).

\section{Writing a Good Read}

Let us return to the substantial level. No doubt the most visible result of a committee's work is the contents of the advisory text. Writing is central to the work performed by the council, which is underscored by the appointment in 1990 of a special editor as well as by the emphasis on training in writing for the staff. Before the final draft is sent to the editor for a finishing touch, letters, discussion papers, chapter-outlines and earlier drafts have been circling among committee members and have structured their deliberations. That so much time and energy is devoted to writing need not surprise: the advisory text can be seen as the laboratory of the committee, the work bench at which the hybrid problems of our time are mobilized, dissected, and reassembled in an innovative way. ${ }^{40}$ Apart from this backstage-function, the advisory report is the vehicle by which the council presents its message to the outside world in order to set others in motion. 
This puts certain demands on the advisory text. In order to transfer the message to the intended audience — the exemplary 'average member of parliament ${ }^{\text {' }}$ — the advice first of all has to be a good read, that is: transparent and devoid of scientific jargon. 'It has to be a readable document: not a highbrow exposition of all kinds of complexities', says the former editor of the council. From a distance, writing a transparent advice may seem a matter of leaving linguistic elements out as much as possible. According to people closely involved in the writing process, such as the secretary and editor, however, transparency is rather the desirable effect of a careful appliance of linguistic means. That brings us to the performative power of an advisory text.

Committees - or at least secretary and editor-are clearly concerned with the possible effects of their advice. In preparing the publication of an advice, much thought is spent on the intended or unintended impact the text may have on its audience (formally: government and members of parliament; in practice also officials in different ministries, and depending on the subject also professional and/or patient-groups, and/or the general public). Former executive director Rigter, for instance, points out that the crucial distinction between science and politics (regarding the position of the Health Council) is partly a matter of literary technique. Exemplary would be the advisory report on the Limits of care ('Grenzen aan de zorg') that he co-authored.

We racked our brains to find a way to write it down so that it would not become a political advice. [Former president of the council] Ginjaar was very strict in these matters. Never before has he refined an advice with neutral formulations like he did with that advice about the limits of care. Because he was a politician himself of course, he knew exactly what a politically charged statement was. And he could also neatly distinguish between these two roles; I know few people who can do that so well. And this really was a query for advice coming from a heavy political context. ${ }^{42}$

In line with Rigter's remarks about the textual means to distinguish between science and politics we will focus on literary technologies of Health Council committees in more detail. But although sorting scientific and political things out on a linguistic level may already prove a highly valued skill, we want to point a bit further. We will argue that what comes out of the advisory-process as scientifically sound and as objective as possible, has first been crafted in the council's laboratory backstage, carved out of heterogeneous materials of partly social origins. An exemplary case in this respect, since firmly rooted in extra-scientific circumstances, is the advisory report Dyslexia; definition and treatment (Gezondheidsraad 1995a).

In the query for advice on dyslexia-signed by the Secretary of state of the Ministry of Welfare, Healthcare and Culture of that time-technical issues regarding insurances have prominence. The direct reason for the query is a recommendation of the Health Insurance Executive Board ('Ziekenfondsraad') in 1990 to exclude language and speech therapy from funding by the Social health care insurance ('Ziekenfondsverzekering') in case of dyslexia. ${ }^{43}$ The reason behind this is a controversy about the value of different forms of treatment of dyslexia, after neuropsychological founded critique on the rationale of treatment by language and speech therapists. Financial issues thus are intricately connected to scientific ones. Therefore, advice of the Health Council is asked about the current level of knowledge concerning this category of severe reading- and spelling 
problems. Questions for the council concern the description and definition of dyslexia, as well as its diagnosis and treatment especially regarding the question in which cases specialist treatment in healthcare institutions is required. Pending the advice, the Secretary of state excluded treatment of dyslexia by language and speech therapists from coverage by the Social health care insurance.

Let us take a closer look at how the committee tries to answer the queries of the State secretary. ${ }^{44}$ Of course it does so by performing its formal task, which is to inform the government on the current level of scientific knowledge. Still, advising the Dutch government and parliament about the level of knowledge must be considered in close relationship to another, more mundane activity, such as telling a story on how to proceed. What literary techniques does the committee apply?

The advisory report on dyslexia is characterized by a careful narrative structure. Potential controversial elements are at first filtered out of the proposed approach of severe problems in reading and spelling and dyslexia. Thus, the report starts of by formulating a working definition of the concept of dyslexia on the basis of - uncontested-'perceptible characteristics' (Gezondheidsraad 1995a, 46) of reading and spelling. In the past, definitions in which (among others) competing hypotheses on the origin of dyslexia were incorporated had caused a lot of controversy in the field. By speaking only of the characteristics that everybody could agree on, the committee coins a definition that includes as many of those involved while excluding everything that has divided them in the past.

Central to the committee's working definition is the term 'automatization' of the word image identification. Usually, children learn to automatically recognize a socalled 'word image'. Typical for such a learning process are a high level of speed and accuracy, it is carried out unconsciously, makes minimal demands on attention, and is difficult to suppress, ignore or influence. In the case of dyslexia, however, a very incomplete or extremely laborious development of reading or spelling occurs. Thus: 'The committee speaks of dyslexia when the automatization of word identification (reading) and/or word imaging (spelling) does not develop or does so very incompletely or with great difficulty' (47).

What initially remains of the object under scrutiny is plain symptoms. No trace of what has preceded the formulation-no explanatory models, disciplinary preferences, or political matters-just observable traits. Political issues linger underneath the surface, to be sure, but the solidity of the working definition as a literary means to keep relevant actors aboard, seems to rest on its matter of factual character. Thus, the advice seeks to escape controversy by allowing a multiplicity of human characters in, while simultaneously leaving their subjectivity out.

The committee emphatically notes that the term 'automatization' in this definition has a 'purely descriptive function' (47). As soon as the report goes beyond factual description and starts to address hypothetical knowledge claims, words are carefully pondered: according to the committee the term automatization 'does as yet not refer to the possibility that a more general automatization-deficit has causal significance, possibly in the context of a more general shortage in information-processing' (47). Caution in moving from matters of fact to their explanation is taken for good reasons: 
although they have been empirically underpinned in a convincing way, 'none of these hypotheses has been accepted as generally valid' (47).

The passage from purely descriptive statements to hypothetical claims is thus carefully managed. But because of the many complexities and problems that characterize the care for people with dyslexia in practice, the committee cannot avoid speaking about societal aspects of signaling, diagnosing and intervening for long. How does the committee make sure that in designing an alternative approach to the problem at stake, the conceptual space that she has first carved out is not immediately replenished with potentially controversial elements (such as conflicting knowledge claims and rivaling professional groups)? The narrative structure of the advisory text is crucial in this regard. The advisory report proposes a systematized approach of reading and spelling problems (including dyslexia) in a stepwise process of signaling, remedying, diagnosing and treatment. In the advisory text this takes the form of a storyline, with different episodes in which relevant professionals are enacted.

By means of the specific way professionals (remedial teachers, speech and language therapists, psychologists, educational psychologists) are embedded in this storylineemphasizing time and place of action-their entrance is subjected to objectifying conditions. For example, 'the committee has decided on a period of no more than 6 months of specific additional assistance within a school using all the aids and expertise available' (25). The actors are thereby detached from their private storylines (about, for instance, contributions made by their own profession to the existing body of knowledge). Instead they are embedded in a new storyline, proposed by the committee, in which there is room for only one leading actor: the dyslexia patient. The contributions of the respective professions are essential to the intended solution, but only to such an extent that their expertise and experience-their appearance in this particular storyserves to contribute to the whole.

Within the advisory report, societal elements in this way get their own fixed place. By enacting them in a stepwise approach, the subject and its unpredictable behavior are brought into the story in a regulated way. Once inside, there is only room for those who keep to the rules. Professionals, professional societies, ministries and others are regularly called upon to act according to these rules (or, where the advisory report only gives a general framework for action, to fill in those rules). This is done neither by imposing certain kinds of action, which is beyond the power of the Health Council, nor by an abstract explanation to the reader on how to proceed. The literally devices that the committee puts to work in order to seduce the audience to comply with the proposed order of things, are far more subtle than that. The council tries to convince its readers by demonstrating what is expected of them.

An important issue in the report on dyslexia, for instance, is the collaboration across sectors and ministerial boundaries (of healthcare and education), which provides another example of the Health Council's mission to contribute to enlarge the scope of control over the hybrid problems of our time. The necessity of this collaboration is substantively argued in the report, but also shown through examples. The advisory text is written in the spirit of mutual co-operation and a sharing of responsibilities between researchers, professional societies and policy departments. In a formalized form, this 
division of tasks should replace and extend the informal ways that patients have found to survive.

Likewise, collaboration (or rather the lack thereof) within the scientific community engaged with dyslexia research is an issue addressed in the advisory report. The scientific character of a scholarly debate is intricately connected to a skeptical, (self)critical attitude, the Health Council believes. However, such an open-minded scientific debate is precisely what is lacking in the field of dyslexia research, according to the council. An exception is made for the neuropsychological treatment method developed by Bakker (member of the Health Council's committee himself). Although (but also because) substantively not uncontested, Bakker's method is empathically praised: 'Much appreciation' exists, the committee writes, for the 'in this field rare way in which the method has been subjected to scientific scrutiny. In spite of this, or rather, as a consequence, the reactions are also critical' (89). 'Bakker' thus plays an exemplary role in the advisory report: he represents the kind of attitude that, in the eyes of the committee, legitimizes scientific contributions to solve the problem at stake. The Health Council's advice on dyslexia thereby exemplifies a regulated performance of actors.

In cases such as dyslexia, where the current state of knowledge is weak and contested whereas social necessity is in dire need of policy, the Health Council seeks to play a legitimate part by outlining a pragmatic way of proceeding. In a context of intertwined clinical interests, suffering patients, rivaling disciplines, contradictory scientific views and policy-lines, linguistic tools are mobilized to help escape controversial history, to control the transition from matters of fact to potentially dividing issues, to regulate entrance and performance of the hybrid characters brought in, and to protect the proposed structure against invading subjectivity. These tools have an objectifying effect insofar they succeed to rearrange relations between unruly elements and to reconstruct social reality in a more predictable, structured way.

\section{Launching the Advice}

Although its mission has formally been accomplished, the committee discharged of its task, and it is now the minister and parliament's turn to move, the political response to an advice once that it has been published and the reception in the media and in the professional press is followed by the Health Council 'with great interest, naturally', says the former vice-president. ${ }^{46}$ At the same time, however, a fundamental lack of interest in the landing of an advice can be signaled. As the former president puts it: 'We deliver an advice, and that's it'. ${ }^{47}$ This does not mean that the scientific staff or committee members personally are indifferent to the impact of the advisory report they helped to produce, on the contrary. Their detached attitude is rather implied and cultivated by the institutional position of the council as an independent advisory board. Beneath the obvious interest in what an advice brings about, a less self-evident but no less significant attitude of indifference is hidden. Such a detached attitude simultaneously helps to establish the product's readymade (and thus its objective) status.

This double standard is even more significant when the council, despite good reasons to refrain, does become actively involved with the landing of an advisory 
report. Sometimes interference is born from necessity. What to do when reactions appear in professional journals that contain actual mistakes or misinterpretations of the original text? Should the council stick to its policy to let go or does one need to react? The council's former vice-president: 'In general we consider it our task to correct actual inaccuracies or interpretative mistakes'. ${ }^{47}$ If reactions on the other hand 'concern a debate on the basis of differences in evaluation... that's all in the game and it's of importance from a societal point of view. After having published an advice, the council shouldn't react separately to that'. Notice the objectifying mechanism: to distinguish between (repair of) 'actual mistakes' and (refrain from interference with) 'different evaluations' enables the council to protect a report from being subjected to deconstructing forces without being forced to meddle with the vicissitudes of politics and implementation.

A comparable partition can be seen in what could be called the missionary work of the council. Members of the scientific staff of the council are wary about deliberately engaging with the settlement of an advice-_quicksand' as one of them remarked referring to any official interference. ${ }^{48}$ Having said that, informal as well as official contacts with the audience the advice aims at are not uncommon at this stage. Communicating the contents of an advisory report in professional settings, co-authoring popular and scientific publications on the basis of an advisory report, and carrying on a lively correspondence are only a few examples. In their capacity as committee-secretary, staff members usually acquire a broad know-how and many contacts in the field. These may be useful when it comes to maintaining public relations for an advisory report. However, the staff is also identified with the institutional face of the Health Council that should emanate neutrality with regard to public health politics and policies, and is thus required to refrain from interference. The dilemma is partly solved by leaving room for restricted involvement of the staff in their personal capacity, partly by leaving the missionary work to the (former) committee members. In 'exchange' for their willingness to further the message of the committee in their respective fields, the latter can profit from some of the council's authority. Notice the objectifying mechanism again: as long as they remain faithful to the spirit of the advisory report, they can pursuit its recommendations with extra (council-informed) authority, without casting doubt on the council's autonomy or the advisory report's objective existence.

Up to here our argument is that after it has published an advisory report, the Health Council mainly needs to prevent political and societal complexities to undermine the readymade stature of the advice (and the legitimacy of the council itself). Thus, we focused on objectifying strategies of the council that should prevent it from being lured into a dispute beyond the actual contents of an advice, while still furthering the message. However, let us consider in closing the launch of Medical practice at the crossroads (Gezondheidsraad 1991) — an advisory report that provides an interesting case precisely because it disturbs the clear cut division of parts sketched above and shifts attention to the importance of the council's surroundings.

The immediate reason for a query for advice in this case was the government's position 'Limits of care' ('Grenzen van de zorg'). The government at the time wished to rationalize care expenditures covered by the Social health care insurance. This would 
have to be realized by removal from coverage of medical procedures of which the effectiveness was non-existent, marginal or unknown. In September 1989 the State secretary of the Ministry of Welfare, Healthcare and Culture asked the Health Council to advice on the effectiveness and efficiency of existing medical procedures (listed by the Health insurance executive board), as well as to address the question whether these procedures should be applied within limits or not at all, and to discuss how proper use could be stimulated.

In his historiography of the Health Council, historian René Rigter $(1992,336)$ qualifies this as a 'fairly improper' query, since the council was asked to declare itself about political choices concerning the services covered by the Social health care insurance. Although it did not want to walk away from the prominent social issue put to the fore by the ministry (the usual consultation between council and department had not taken place), the board of the Health Council wanted to prevent that the council was made to practice politics under the guise of scientific advice. 'We were especially keen on not being maneuvered into a position in which we had to say: "such and such services have to be skipped". That would really have brought us at cross-purposes with politics', according to the secretary who signed for the advisory report. ${ }^{49}$

Because of its objections the council used its leeway to adjust the problem-definition of the ministry. The query of advice was written with the assumption that certain medical services could be completely canceled, which is rarely the case in medical practice. 'It is a much more difficult story', according to the executive director of the Health Council at the time, Rigter, who refers to 'a heavy politicized context' in which the council had to navigate. ${ }^{50}$ 'Removal of services (from funding) will not-or hardlybe defensible on scientific grounds', according to the staff in a committee's meeting. ${ }^{51}$ The extent to which a procedure has the intended effect is in practice connected to various medical and non-medical factors that can mitigate the efficacy. Thereupon it was decided to avoid judgments on the efficiency of individual procedures and to concentrate on medical practice instead. Efficiency then was defined as 'the extent to which a procedure has the intended effect in everyday practice' (Gezondheidsraad 1991, 7), taking into account social, cultural, organizational and other factors that may bear upon the effectiveness.

Thus the problem has shifted: from the individual procedure to the situation-everyday practice, the social circumstances, the financial framework-a procedure became part of. That move is justified by an appeal to the necessity of keeping political hot issues out and of restricting oneself to what can be objectively determined. The tenability of the council's appeal on objectivity, however, has also been seriously questioned. The planned release of Medical practice at the crossroads in December 1989 caused some consternation, related to the presentation of the advisory report in the council's press release and the objective caliber of the advice. One day before publication, a memo signed by the director of the Staff office Policy development ('Stafbureau Beleidsontwikkeling' or Stabo) was sent out to the director-general Healthcare (both of the Ministry of Welfare, Healthcare and Culture). In his memo the director expresses his concern about drafts of the council's advisory report and press release that have come under his attention. According to the Staff office-think tank of the director-general 
Healthcare and initiator of the request of advice - the Health Council has exceeded its scope by advising on societal (instead of scientific) problems and thus challenges a neighboring advisory board, the National Council for Health Care ('Nationale Raad voor Volksgezondheid' or NRV) on its territory. ${ }^{52}$ Although the official admits that the ministry 'may in the past have contributed to pressure on the council's boundaries by including "improper" elements in a query of advice', this particular request did not. Thus, he thinks that ' $\mathrm{i}$ ] t is desirable to consult the Health Council-in a general senseon the demarcation of its task. In this report topics appear such as financial prompts, collaboration [of] general practitioner[s] and specialist [s], manpower planning, which are NRV's affairs'. 53

Health Council, confine yourself to what can be objectively determined-thus reads the diagnosis of the Staff-office. Publication of the report as such is uncontested; the controversy focuses on the accompanying press release. According to the memo it would need adjustment: 'Emphasis should be put on scientific insights [concerning] medical procedures (diagnostics and treatment)'. ${ }^{54}$ The director-general Healthcare thereupon contacts the State secretary, whom he informs that he Health Council has exceeded the bounds of scientific advising. Afterwards, Health Council representatives acknowledge that this critique made sense. 'I must admit that I found it a borderline case myself, says former vice-president of the Health Council and committee-chair Borst. To put it mildly: statements on consequences of the Dutch remuneration system, says Borst, brought the council 'in fact in the middle of politics' ${ }^{55}$ In the press release, however, the council would have gone beyond the pale even more empathically, the department holds. The contested draft is disqualified as being 'populist' and the council is contacted in order to adjust the text. By putting more emphasis on scientific findings the department seeks to hide undesirable elements form the contents of the advice:

I was alarmed about the press release that I had read. Thereupon I contacted Mrs. Borst, vice-president of the Health Council and conveyed my concern to her. After that I had been able to get to know the report itself I have been in contact with her again. My concerns were of a dual nature:

1. The style of the draft press release had a rather populist tone of voice and consequently would receive more attention than was strictly necessary, considering the contents of the report.

2. The remarks in the press release and in the report do not all concern reporting on the level of scientific knowledge but have markedly policy-related and even maybe political sides.

The consultation with Mrs Borst has resulted in the adjustment of the press release on the main points, which at least made the populist character disappear. ${ }^{56}$

Instead of a neutral representation of the contents of an advisory report, the press release here appears as a boundary-zone, where the Health Council is positioned partly by others. 57

Once the advisory report is published, we have argued here, objectifying strategies to sort things out are still in place. By distinguishing between actual mistakes and different evaluations, formal and informal links, clarification and evaluation, the council seeks 
to protect the outcomes of a committee process from being turned into 'just another opinion' next to others, a product of human choices rather than a readymade object out there. However, we have also seen that the aim of the council to extend control over the hybrid problems of our time-including social, political, even irrational aspects of medical practice-implies that its advisory work turns out to be a real balancing act. Where the council is considered to cross the line between what appears as scientific advice and politics, however, it appears that the council's surroundings-notably the policy department - has its own interest in keeping a body at hand, whose impartiality is esteemed beyond doubt and whose products can thus be relied upon in policymaking. Rather than being subjected to doubt, this proverbial hybrid called the Health Council, thus becomes objectified here: by other actors asking the council to live up to the ideals that are constitutive for the council's legitimacy and authority of scientific advice.

\section{Conclusion: Objectivity beyond the Species Barrier}

At the beginning of the twenty-first century, scientific advisory work for public policy making has become a complex affair. The leading characters are entangled in all kinds of dangerous liaisons. Even for an independent advisory board such as the Health Council no escape is available from the increasing intertwinement of scientific and societal processes. This, however, has not brought the Dutch government to question the legitimacy of the council's appeal to scientific values. Indeed, we can hardly imagine the work of the Health Council without at least some notion of objectivity. Spokespersons in- and outside the Health Council, however, make clear that such an idea of objectivity is not to be confused with idealized notions of objectivity, conceived as an inherent quality of the scientific method or community. According to what Rigter (1992) has learned from 90 years of Health Council advice, advise based purely on scientific facts-although formally what the council is supposed to do-can never be attained for 'a full hundred percent'. But it should not be considered 'a fiction' either. Being as objective as possible (to borrow from the phrasing of the Minister of Health in parliament) for the Health Council is 'not a factuality but a challenge, a task that has to be fulfilled as best one can, time and again' (Rigter 1992, 336).

In line with these findings we have chosen to ask how this mission is pursued in the everyday practice of the advisory process. The aim was to get our fingers behind a notion of objectivity that allows for the possibility that it has to be kept alive or reinvented under circumstances of ever-expanding, intimate links between scientific research, trade and industry, national and International policymaking, irrational feelings, ethical considerations, technological innovations, etc. If we have indeed gone beyond the species barrier, at the substantial (object) level as well as on the procedural (council) level, what then does scientific advisory work look like? And how can the idea of objectivity still make sense?

We have argued that objectivity is not a ready made criterion residing outside the complex relationships mentioned above, but a family of characteristics brought about by way of reframing, reconfiguring, rearranging, and redistributing existing elements 
and features; characteristics which are moreover effectuated exactly in the monstrous liaisons that seem to be denied by the very idea of objectivity.

To be sure, the characteristic ways these hybrids are dealt with by the Health Council can partly be understood in terms of what Thomas Gieryn (1994) has called 'objectivity as denial'. The style of denial can first be traced in the Health Council's work on a substantial level, for instance when it distinguishes between different kinds of problems: the ones that can be domesticated (by fitting them into legal procedures, established ways of reasoning, measuring, etc.) and the ones that threaten to foster endless debate (so-called rest problems, personal feelings, etc.). The denying style of objectification is also found on the institutional level, for instance when it filters out strong conflicts of interests in the experts who are invited to form a committee, and in the council's refusal to become entangled in matters of politics and implementation after an advice has been published.

Other aspects of the Health Council's work, however, seem to go beyond such efforts to harness the species-barrier between science and society, while still trying to retain some sense of objectivity. On the one hand, the council seems to rely on experts who put their knowledge at society's disposal in a disinterested way (rather than on seeking the truth; cf. Dear, 1992). Yet, the council also turned out to acknowledge the intimate links that science, commerce, and the state have begun to entertain, and to have learned to cope with the kind of expert in whom these worlds meet. Certainly, it does not seem far-fetched to interpret the council's reliance on ethical argumentations that are independent of particular conceptions of the good life in terms of what Daston (1992) has called an 'escape from perspective'. Yet, we have also come across voices claiming that so-called neutral ethical considerations are as particular as any, which opens up the possibility of allowing members in who adhere to religious principles. Their contributions could still be objective, as long as they submit to the same critical inspection the others accept. Or, to borrow from Daston and Galison (1992), the council's dependence on standardized methods and frames of reference may very well be framed in terms of 'mechanical objectivity'. Yet, the trust invested in experts who are appointed in their personal capacity and who are acknowledged as an authority in their field, shows that personal objectivity (Porter, 1995) still plays an important role (such raw human input turns out to be carefully molded to fit the form of life of the advisory board).

The case of the Health Council underscores the importance of a special place in society where complex problems of our time can be dealt with in a way which is neither reducible to science nor to politics. But how stable is such a 'third position'? As one of our informants from abroad predicted, pleas for democratizing governance will certainly leave their marks on the future role of the Health Council.

I cannot imagine that in twenty years time in Holland you will not have some form of involvement of consumers in policy making around science. Whether it will be by having them formally put into the Health Council, or whether it will be by the government actually having to set up his own policy making process that the Health Council just becomes an input to, I don't know. But my guess is that in twenty years time they'll be somewhere-not least because in some countries they're everywhere! ${ }^{58}$ 
What is significant about our analyses in the light of recent debates about the role of expert knowledge, ethics, and democratic governance (cf. Gottweis 2003; Jones 2003), is that they articulate what it takes to continually create and maintain a place in society where problems are considered in a way not reducible to either science or politics. When extending the scope of its activities and when allowing new actors in, utmost care is taken by the council to embed such elements in trusted upon formats, to reconfigure the experts, to fine-tune voices by applying technologies of speech, etcetera. Thus, the Health Council's procedures can be seen to provide a critical note to an unconditioned faith in the ability of 'raw', not elaborated upon human input (such as in citizen's panels, public hearings, etcetera) to counter the crisis in governance of the complex problems of our times.

Scientific advisory work in an era of intimate connections between science, technology and human values is necessarily reflexive in character. Yet, the fact that the Health Council is obliged to include all kinds of non-scientific elements in the advisory process does not turn it into a full-blown political actor. Significant is not the council's aim to cope with the hybrid problems of our time per se, but the specific way these imbroglios are treated and gradually re-worked during the advisory process. In its ability to impose a new form, to set the conditions, to almost carve out so-called objective characteristics in the raw working materials the council is confronted with, the Health Council's legitimacy is found. Objectivity is an achievement brought about by flexible tools in the hands of ordinary yet skilled people working under extraordinary circumstances.

\section{Acknowledgements}

We would like to thank participants and commentators at the 'Objects of objectivity' workshop, Amsterdam, September 18-19, 2003, and of the BOTS 'Summer harvest', Maastricht, September 24, 2003, and Ruth Benschop in particular, for their critical remarks on previous drafts of this article.

\section{Notes}

[1] The idea for an $\mathrm{ABC}$ is borrowed from: Hacking, 1999. In compiling this $\mathrm{ABC}$, we made use of the overview of Health Council's advisory reports 1902-1992 in: Rigter, 1992, Appendix III. In this case, as throughout the paper, sources originally in Dutch were translated to English by us.

[2] See, for a history of the (Central) Health Council 1902-1985: Rigter (1992). According to Rigter the Central Health Council had a dual structure: it was supposed to advise on medicalscientific problems as well as on societal issues, and had to fulfill administrative as well as advisory tasks. The Health Act of 1919 reshaped the council into a board with an exclusively advisory task. In order to support the government in her interference with regard to public health, experts from a variety of medical and other scientific disciplines, as well as representatives of professional and societal organizations, were invited to take place in the Health Council. In between the two World wars, the council developed in quite another direction than was defined by law, partly because of the policy of its president of the time. By hardly admitting representatives of interested parties but predominantly scientific experts in the 
Health Council's committees, the foundation was made for a strictly scientific advisory board. This delineation was confirmed by the Health Act of 1956, which also provided for a separate advisory body with representatives from social and professional organizations and governmental bodies, which would focus on societal aspects of public health (cf. the debate described in section 4).

[3] Requests for advice predominantly come from the Ministry of Health, Welfare and Sports, the Ministry of Housing, Spatial Planning and the Environment, the Ministry of Agriculture, Nature Conservation and Fishery and the Ministry of Social Affairs and Employment. Apart from responding to ministerial queries, the council is entitled to prepare advisory reports on its own initiative.

[4] According to Weingart (1999) this comes to expression in, among others, the many public controversies around scientific activities, and the criteria of political representativeness and transparency that are increasingly imposed on scientific boards. Whereas boundary-work has enabled science to demand a cultural space in which epistemological authority could be claimed (Gieryn 1983), the increasing call for openness about the intricate ties between science and politics lead to a loss of authority (also see: Ezrahi 1990).

[5] Whereas the political sciences have called attention to the 'displacement' of politics to, amongst others, science and technology (e.g., Beck 1997), scholars in Science and Technology Studies have shown that science can be fruitfully described as 'politics by other means' (e.g., Latour 1987).

[6] According to Jasanoff $(1990,250)$ regulatory science should strive for a 'serviceable truth', i.e., a 'state of knowledge that satisfies tests of scientific acceptability and supports reasoned decision-making, but also assures those exposed to risk that their interests have not been sacrificed on the altar of an impossible scientific certainty'.

[7] Studies in public understanding of science have shown that intervening in societal practices can only be successful if the specific structure and organization of these practices is anticipated during the advisory-process aimed at intervening. The authority of the expert depends on whether science understands its public (Wynne, 1995; Hagendijk and Wouters 1999).

[8] This article is based on research commissioned by the Health Council in the context of its one hundred year's anniversary. The study consisted of 10 detailed case studies in which exemplary advisory reports of the council were followed from there preparation to their implementation, a general round of interviews, and a series of nine focus groups in which preliminary conclusions were checked. The following cases were studied: Antimicrobial growth enhancers (1998); Dioxins (1996); Dyslexia: definition and treatment (1995); Heredity: science and society (1989); Man-made mineral fibers (1995); Medical practice at the crossroads (1991); Risk assessment of manual lifting (1995); Vitamin A and teratogenicity (1994); Zinc (1997); Xenotransplantation (1998). For an extensive account of our results (in Dutch), see: Bal et al. (2002).

[9] Apart from answering to ministerial queries the Health Council also has a role in signaling problems. In the case of xenotransplantation this 'signal' is published in: Gezondheidsraad (1995b, 34-7).

[10] Xenotransplantation Committee, minutes 1st meeting of January 13, 1997, p. 4. Archive Health Council, 550-33.

[11] It sometimes happens, however, that the council is confronted with a ready-made query. Even then, the council has the possibility to give a different interpretation (cf. section 4).

[12] Dr W. J. Dondorp, scientific staff Health Council, secretary of the Standing Committee on Medical Ethics and Health Law. Interview: The Hague, May 9, 2000. The Health Council hosts eight of these standing committees, each of which deals with a broader subject area than those covered by the ad hoc committees. The key role of the standing committees is to advice the president of the Health Council on the mission and composition of advisory committees and to peer review draft committee reports in their domain. The following standing committees are presently in existence: Medicine, Medical Ethics and Health Law, Infectious Diseases and 
Immunity, Genetics, Nutrition, Health and Environment, Radiation Protection, and Ecotoxicology.

[13] In September 1995, the British company Imutran had announced clinical experiments with genetically modified pig hearts in England in 1996. The British government was caught by surprise and proclaimed a moratorium on clinical experiments. Under the influence of optimistic news coverage public opinion, however, was supporting the industry's plans. The government decision thus provoked fierce response from the patient movement, as if the British government was already responsible for people dying on an imagined waiting list for a xenograft. See for this controversy and the claims of Imutran's Dr White that fostered it: Dickson, 1995. Just as an appetizer: 'White, however, firmly rejects charges that his company is guilty of raising unfair expectations-and in particular that last week's announcement via the press was partly motivated, as some have suggested, by the need to raise more venture capital to support further experiments' (185-86).

[14] Dr G. J. Olthof, Ministry of Health, Welfare and Sport; advising member Xenotransplantation Committee. Interview: The Hague, September 11, 2001.

[15] Professor Dr A. J. Dunning, chair Xenotransplantation Committee. Interview: Abcoude, July $12,2001$.

[16] Gezondheidsraad (1998a, 16). Environmental Hazardous Substances Act = 'Wet milieugevaarlijke stoffen'.

[17] For debates in STS about the (problematic) boundaries between humans, animals and machines, see: Lynch and Collins (1998).

[18] Question (3) about the ethical assessment of clinical research in humans, may at a first sight seem to invite the committee to engage into fundamental discussions on the desirability of human-animal-technology hybrids instead of restricting the scope to what can be processed within established formats. An endless debate, however, is precisely what was not meant to happen. Hence, what on second thoughts turns out to be a procedural question: 'How can ... a well-considered, guiding judgment be obtained on the ethical acceptability of [protocols for clinical xenotransplantation experiments]?' (Query for advice on Xenotransplantation, December 31, 1996, kenmerk CSZ/ME-9615719. Archive Health Council, 550-30). In line with that formal question the committee's answer would be: charge the Central Ethical Review Committee that will be installed as part of the forthcoming Medical Research involving Human Subjects Act ('Wet medisch-wetenschappelijk onderzoek met mensen') with a supervisory task. Which is not to suggest that ethical aspects are welcomed only when they come in a procedural format. On the contrary, many advisory reports discuss ethical issues in an extensive and substantive way. An exemplary case is the report Heredity: science and society (Gezondheidsraad 1989).

[19] See: W. J. Dondorp and J. S. Reinders, Standing Committee on Medical Ethics and Health Law, Discussion paper on ethics, June 15, 1998, pp. 2-3. Archive Health Council, 125-2493.

[20] See: W. J. Dondorp and J. S. Reinders, op cit., pp. 2, 3.

[21] Dr W. J. Dondorp. Interview: The Hague, May 9, 2000. The committee was in fact reproached to remain too sketchy with regard to the ethical aspects of the use of animals: little is studied in depth, no arguments are given, there is too little anticipation on public concerns, and the responsibility is delegated too much to the Biotechnology in Animals Committees ('Commissie Biotechnologie bij Dieren') without bringing up building blocks for the ethical discussion itself. See for this critique: Standing Committee on Medical Ethics and Health Law, Gedeelte uit verslag van de $93^{\mathrm{e}}$ vergadering van 27 november 1997. Archive Health Council, 550-149.

[22] Discussion on this topic was fostered by question (3) - 'Is it ethically acceptable ... to ... breed genetically modified animals with the objective to have them serve as a source for substitute-organs for humans?'-which indeed seems to go beyond the more usual, but less fundamental question to indicate which ethical, legal and social aspects are relevant for decision-making. However, notice the minister's addition that she is aware that 'such questions on the possible unacceptability and ethical objections ... should (soon) be answered in the 
advisory reports regarding this issue of the Biotechnology in Animals Committees, that will be installed as part of Article 69 of the Animal Health and Welfare Act'. (Query for advice on Xenotransplantation, December 31, 1996, kenmerk CSZ/ME-9615719. Archive Health Council, 550-30.). In this framing, the reserved approach was contained from the start.

[23] Dr E. van Rongen, scientific staff Health Council, secretary Xenotransplantation Committee. Interview: The Hague, December 14, 2000.

[24] 'At a political level it is often assumed that this wider approach [including personal feelings among others] will lead to nothing but never-ending discussion on pointless questions about personal feelings' (Hilhorst 1998, 195).

[25] Hilhorst $(1998,195)$. In fact, Hilhorst warns for the side-effects of the exclusion of these 'restproblems' from public discourse: 'It may be that today aspects of life, such as smell and taste, have a stronger appeal than more regular, too often heard arguments concerning health, environment or animal welfare' (p. 187). According to some people these types of arguments 'are not morally sound' and do not belong in the public domain (p. 185). According to Hilhorst, however, "ii]t can be argued that these individual, "emotional" feelings are part of public fear and should be conceived as morally relevant' (p. 187). Delegation of these issues to the private sphere would be regrettable because it would deprive us of the chance to learn something from these personal considerations, and would automatically imply support for the dominant view in society. Hilhorst finds it plausible that if we go on to discredit them 'so-called "rest" problems, vague feelings and moral intuitions, will accumulate and leave us with growing and severe costs of all kinds: uneasiness and guilt over animal use, alienation from our bodies and from our (living) environments, a (mis)perception of the one-sidedness of values in our way of living, sharpening disputes within society, isolation of given cultural groups, etc.' (p. 194).

[26] See: W. J. Dondorp and J. S. Reinders, op cit., p. 8.

[27] In this, they follow the critics inside the Xenotransplantation Committee and in the Standing Committee on Medical Ethics and Health Law itself, who argued that the question on animal ethics had been interpreted too narrowly, in terms of risk-assessment only.

[28] Dr E. van Rongen. Interview: The Hague, December 14, 2000.

[29] The advice on Risk assessment of manual lifting (1995) is a good example. See: Bal et al. (2002).

[30] Prof. Dr L. Ginjaar, president of the Health Council December 1, 1985 to April 1, 1996. Interview: The Hague, December 18, 2002.

[31] Prof. Dr J. A. Knottnerus, vice-president of the Health Council April 1, 1996 to September 2001, president of the Health Council since September 1, 2001. Interview: The Hague, December 4, 2001.

[32] Dr B. Sangster, former director-general Public Health, Unilever N.V. Corporate Centre. Focus group with users in the domain Health and Nutrition: March 28, 2002. A discussion on the honoraria of Dutch experts compared to what would be internationally customary, elicited the statement from Sangster that universities here are loosing the race with (international) trade and industry. The Health Council too, would have more and more difficulties to get the best people. However, where it concerned the payment of committee members, he deliberately reacted with great hesitance (cf. the quote). Prof. Dr W. F. Passchier, deputy executive director Health Council as of December 1, 1983. Interview: The Hague, January 15, 2002, understated: 'I think that people who primarily care about protecting public health have a better chance to end up in a committee than people who say: let us make some money here'.

[33] As president of the European Scientific Group for Influenza Osterhaus, professor of virology and at the time member of the Xenotransplantation Committee, e.g. organized a meeting for members of the European parliament and various stakeholders, hosted by Euro commissioner Byrne. Objective: to coordinate pressure on policy in the member states. Prof. Dr A. D. M. E. Osterhaus. Interview: Rotterdam, July 11, 2001.

[34] An earlier draft of the manual focused specifically on openness regarding any financial interests, thus the fight against conflicts of interest has broadened. It has also become more formalized, among others with regard to reporting and accountability vis-à-vis third parties. The 
most recent update of the Conflicts of interest section requires candidate-members to complete a form that specifies different categories of possible interests (commercial, social, scientific, personal). Their statements are taken into consideration by the council's president when deciding on appointment of members. The disclosure round during the installation meeting is held in addition (Prof. Dr J. A. Knottnerus (e-mail correspondence, July 29, 2002, 16:44 hours).

[35] We elaborate on this point in: Bal et al. (submitted).

[36] J. W. Dogger, MSc, scientific staff Health Council. Interview: The Hague: 28 January 2002. Other secretaries for example point at the minutes of committee meetings as a point where they can discipline committee members, for example by formulating some conclusions sharper than actually said, or by explicitly mentioning that some discussions are repeated several times. Focus group Committee secretaries, March 12, 2002.

[37] In Dutch: 'Dat maakt dat je iets vrijer je gang kunt gaan en dat mensen meer bereid zijn om het achterste van hun tong te laten zien. Want dat wil je' (Prof. Dr J. A. Knottnerus. Interview: The Hague, December 4, 2001). A comparison of the Health Council's concept of 'onbevangenheid' or frankness with the antique Greek concept of 'parrèsia', taken up by Foucault and borrowed by Marli Huijer (2003) in her inaugural lecture Vrijmoedig spreken; publieke gesprekken over gender en biotechnologie (Faculteit der Cultuurwetenschappen, Universiteit Maastricht) seems fruitful. In both cases truth is at stake. Huijer: 'Someone using parrèsia is someone who is speaking frankly, with candor and honesty. He speaks from his heart and soul, from a sensible mind, without rhetoric, without tricks, and without tactics or strategic aims. What is at stake in "candid speaking" is truth' (p. 16). However, there is also an important difference, because in Greek literature parrèsia is always connected to danger: the person who is spoken to is more powerful than the person who is speaking up, as Huijer points out. Such differences in power may occasionally occur, but are certainly not immanent to a Health Council committee's situation. Still, the council's technologies of speech may contain interesting lessons for the design of public debates (on biotechnology).

[38] An example concerns the Anti-microbial growth enhancers committee that had to navigate in a very controversial context, in which pressure groups (representing farmers, cattle feed industry, and producers of antibiotics) paid close attention to what happened. Halfway the trajectory, the committee's chairman Van Boven, during an interview with the NOS television news, let slip the remark that a ban on anti-microbial growth enhancers was likely necessary. Also one of the members of the committee, Van den Boogaard, had said that in public. The sector organization NEFATO of the cattle feed supplements industry jumped on it and accused both of being prejudiced. The president of the Health Council immediately decided to discharge Van Boven of his chairmanship and membership of the committee. Bosman, secretary of the Health Council but at the time advising member of the committee: 'We have certain mores in the Health Council and this is really not done' (Ir. W. Bosman, scientific staff Health Council. Interview: The Hague, May 14, 2001). Van den Bogaard did not need to resign, since he had taken care to not speak in his capacity as a committee member but as an individual researcher; he thus was not considered to have broken the confidentiality of the committee process.

[39] In response to the 'Wet Openbaarheid van Bestuur' all sorts of measures have been taken to maintain a sharp distinction between the back and the front region, e.g., by having summaries of minutes for public display while keeping the minutes themselves-which are an important part of the stage management of committees—out of public scrutiny. Nevertheless, also within the council, pleas are made for greater openness. As 'advocates of the reader' the new editors of the council for example would want to show more of the committee process in advisory reports: 'Much weight is put on the committee and this is also publicly expressed, like "the committee considers this to be the case or not", but how that committee has done its work... As a reader, you usually don't get much insight in the committee process. It simply says "believe us on our good reputation, this is the way it is, the committee has decided." In 
the age of an emancipated citizenry, I don't think it to be sufficient any longer to say, "we've weighed the matter and this is the result." You must show some of the considerations that went into that process, something about the history of the advice, what was easy or difficult about it or where conflicts were' (Dr M. S. de Waal and Dr P. Slot, editors Health Council. Interview: The Hague, May 4, 2002).

[40] Miller (2001) has proposed the term hybrid management for these activities of boundary organizations.

[41] A. B. Leussink. Interview: The Hague, July 5, 2001. Identifying members of parliament as the implied audience, the secretary of the committee advising on dementia writes to the committee: 'The committee will pursue a clear, concise, inspiring document that states the main lines of argument, reflections and views in a way that is knowledgeable to the interested lay person'. Secretary Committee Dementia, Uitgangspunten ('Starting-points'), January 10, 2000, p. 3. Archive Health Council of The Netherlands, 655-1.

[42] Prof. Dr H. G. M. Rigter, executive director Health Council August 1, 1983-December 31, 1992. Interview: Utrecht, December 19, 2002.

[43] The Dutch health care system has a mixed insurance, in which people up to a certain amount of income are compulsory insured by the Social health care insurance, and above that level have private insurance. Although private insurers decide on their own insurance policy, they tend to follow policies set by the Health Insurance Executive Board. The time lag between the Health Insurance Executive Board's advice and the query for the Health Council (dated May 24,1993 ) is explained by the low political priority of the issue.

[44] In conceptualizing linguistic ordering devices, we will borrow from Shapin and Schaffer's (1985) ideas about literary technologies. We will also loosely employ some of the concepts of narrative analysis: character, storyline, and plot-structure.

[45] Prof. Dr J. A. Knottnerus. Interview: The Hague, December 4, 2001.

[46] Prof. Dr L. Ginjaar. Interview: The Hague, December 18, 2002.

[47] Prof.. Dr J. A. Knottnerus. Interview: The Hague, December 4, 2001. An exemplary case described in Bal et al. (2002) is the 1994 advisory report Vitamin A and terratogenicity.

[48] Drs W. J. Dogger, scientific staff Health Council. Focus group with committee-secretaries: March 12, 2002.

[49] Dr Y. A. van Duivenboden, secretary Standing Committee on Medicine. Interview: The Hague, November 1, 2001. The Standing Committee on Medicine, successor of the 'College van Advies en Beraad', in this case operated as the advisory committee. Vice-president of the Health Council, Borst, signed as committee-chair.

[50] Prof. Dr H. G. M. Rigter. Interview: Utrecht, December 19, 2001.

[51] Dr Y. A. van Duivenboden. Interview: The Hague, November 1, 2001.

[52] This council is nowadays known as the Council for Public Health and Health Care ('Nationale Raad voor de Volkgezondheid en Zorg'), with representatives from social and professional organizations and governmental bodies, which focuses on social, legal and organizational queries regarding public health.

[53] Memorandum Director STABO to Director-General Healthcare Sangster, December 11, 1991. Copy of document in archive rh.

[54] Ibidem. The president of the Council points out that negotiating on the draft of a press release is nowadays unthinkable. Prof. Dr J. A. Knottnerus, E-mail message, August 20, 2002, 20:04 hours.

[55] Dr E. Borst-Eilers. Interview: The Hague, February 27, 2002.

[56] Note of Director-General Healthcare to State secretary to secretary of state Simons, December 12, 1991. Copy of document in archive rh.

[57] See for the concept of 'boundary-zone': Galison (1996). See for an application: Derksen (1999).

[58] Dr Chr. Henshall, Director Science and Engineering Base Group. Focus group 'Foreign and International organizations', April 18, 2002. 


\section{References}

Bal, R., W. E. Bijker, and R. Hendriks. 2002. Paradox van wetenschappelijk gezag. Over de maatschappelijke invloed van adviezen van de Gezondheidsraad. Den Haag: Gezondheidsraad.

- Submitted. Committees at work; the Health Council of The Netherlands and the staging of science advice. Draft chapter prepared for R. Sujatha and D. Guston, eds. Science Boundaries Policy: New Research.

Beck, U. 1999. World risk society. Oxford: Polity Press.

Benschop, R., and D. Draaisma. 2000. In pursuit of precision: the calibration of minds and machines in late nineteenth-century psychology. Annals of Science 57: 1-25.

Brown, N. 1999. Xenotransplantation: normalizing disgust. Science as Culture 8: 327-55.

Collins, H. M. 1985. Changing order: replication and induction in scientific practice. London: Sage.

Dehue, T., and R. de Wilde. 2001. Inleiding. 'Objectiviteit' als menswetenschappelijk instrument en argument. Paper presented at the WTMC voortgangsconferentie, Leusden, 21/22 November 2001.

Derksen, M. 1999. Iedereen doet aan psychologie: demarcatie en retorica in de Nederlandse psychologie, 1892-1992. Groningen: Historische uitgeverij.

Daston, L. 1992. Objectivity and the escape from perspective. Social Studies of Science 22: 597-618.

Daston, L., and P. Galison. 1992. The image of objectivity. Representations 40: 81-128.

Dear, P. 1992. From truth to disinterestedness in the seventeenth century. Social Studies of Science 22: 619-31.

Dickson, D. 1995. Pig heart transplant 'breakthrough' stirs debate over timing of trials. Nature 377: $185-86$.

Ezrahi, Y. 1990. The descent of Icarus: science and the transformation of contemporary democracy. Cambridge, MA: Harvard University Press.

Galison, P., and D. J. Stump, eds. 1996. The disunity of science: boundaries, contexts, and power. Stanford, CA: Stanford University Press.

Gezondheidsraad 1989. Erfelijkheid: wetenschap, en maatschappij. Over de mogelijkheden en grenzen van erfelijkheidsdiagnostiek en gentherapie. Den Haag: Gezondheidsraad.

- 1991. Medisch handelen op een tweesprong. Rijswijk: Gezondheidsraad.

- 1995a. Dyslexie. Afbakening en behandeling. Den Haag: Gezondheidsraad.

- 1995b. Jaaradvies Gezondheidszorg 1994-1995. Den Haag: Gezondheidsraad.

. 1995c, Risicobeoordeling van handmatig tillen. Den Haag: Gezondheidsraad.

. 1998a. Xenotransplantatie. Den Haag: Gezondheidsraad.

. 1998b, Antimicrobiële groeibevorderaars. Den Haag: Gezondheidsraad.

. 1998c. Zink. Den Haag: Gezondheidsraad.

. 2000. Jaarverslag 2000. Den Haag: Gezondheidsraad.

. 2001. Prenatale screening: Downsyndroom, neuralebuisdefecten, routine-echoscopie. Den Haag: Gezondheidsraad.

. 2001. Vademecum voor secretarissen. Version June 2001. Den Haag: Gezondheidsraad.

. 2002. Algemene informatie over taak en werkwijze van de Gezondheidsraad en zijn commissies.

Den Haag: Gezondheidsraad.

Gezondheidsraad and Voedingsraad. 1994. Vitamine A en teratogeniteit. Den Haag: Gezondheidsraad en Voedingsraad.

Gieryn, T. F. 1983. Boundary-work and the demarcation of science from non-science: Strains and interests in professional ideologies of scientists. American Sociological Review 48: 781-95. . 1994. Objectivity for these times. Perspectives on Science 2: 324-49.

Gusfield, J. R. 1981. The culture of public problems: drinking-driving and the symbolic order. Chicago, IL, and London: The University of Chicago Press.

Gottweis, H. 2003. Embryos for Europe: emerging strategies and institutional solutions. Paper prepared for the Workshop 'Assessing emergent forms of governance: European public policies beyond the institutional void. ECPR, Edinburgh, March 28-April 2, 2003. 
Hacking, I. 1999. The social construction of what? Cambridge, MA, and London: Harvard University Press.

Hagendijk, R., and P. Wouters. 1999. Public understanding of science and governance. STS after 2000. Kerkrade: WTMC.

Hilhorst, M. 1998. Xenografting as a subject for public debate. In P. R. Wheale, R. von Schomberg and P. Glasner, eds. The social management of genetic engineering, pp. 183-99. Aldershot: Ashgate.

Huijer, M. 2003. Vrijmoedig spreken; publieke gesprekken over gender en biotechnologie. Maastricht: Universiteit Maastricht.

Jasanoff, S. 1990. The fifth branch: science advisers as policymakers. Cambridge, MA: Harvard University Press.

Jones, M. 2003. Policy legitimation, expert advice, and objectivity: the restructuring of the UK governance framework for human genetics. Paper presented at the workshop 'Objects of objectivity'. WTMC, Amsterdam, September 18-19, 2003.

Latour, B. 1987. Science in action: how to follow scientists and engineers through society. Cambridge, MA: Harvard University Press. . 1993. We have never been modern. Hemel Hempstead: Harverster Wheatsheaf.

Lynch, M., and H. M. Collins, eds. 1998. Science, technology, \& human values, 23:4, Special issue: Humans, Animals, and machines.

Miller, C. 2001. Hybrid management: boundary organizations, science policy, and environmental governance in the climate regime. Science, Technology, \& Human Values 26: 478-500.

Pels, D. 2001. Wetenschap als onthaasting. En onthaasting van de wetenschap. Krisis; tijdschrift voor empirische filosofie 2: 6-25.

Porter, T. M. 1995. Trust in numbers: the pursuit of objectivity in science and public life. Princeton, NJ: Princeton University Press.

Rigter, H. G. M. 1987. De Gezondheidsraad. In R. Janssen, P. Kocken and J. van der Made, eds. Externe adviesorganen in de gezondheidszorg, pp. 139-48. Lochem: De Tijdstroom.

Rigter, R. B. M. 1992. Met raad en daad: de geschiedenis van de Gezondheidsraad 1902-1985. Rotterdam: Erasmus Publishing.

Shapin, S., and S. Schaffer. 1985. Leviathan and the Air Pump: hobbes, boyle, and the experimental life. Princeton, NJ: Princeton University Press.

Tweede Kamer. 1996a. Begroting VWS, TK 1995-1996, 34 2748. Den Haag: Tweede Kamer.

- 1996b. Wijziging van de Gezondheidswet in verband met de continuering van de Gezondheidsraad; nota n.a.v. het verslag, TK 1996-1997, 24 684, nr. 5. Den Haag: Tweede Kamer.

Wilde, de R. 2001. De kenniscultus: over nieuwe vormen van vooruitgangsgeloof. Maastricht: Universiteit Maastricht.

Weingart, P. 1999. Scientific expertise and political accountability: paradoxes of science in politics. Science and Public Policy 26: 151-61.

Wynne, B. 1995. Public understanding of science. In G. E. M. S. Jasanoff, J.C. Petersen and T. Pinch, eds. Handbook of science and technology studies, pp. 361-88. Thousand Oaks, etc.: Sage Publications. 